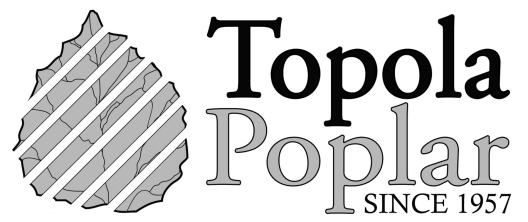

Original scientific paper

\title{
Environmental assessment of greenhouse gases' emission in poplar plantation under extreme climate conditions of winter 2019/2020
}

\author{
Miljan Samardžić ${ }^{*}$, Zoran Galići ${ }^{1}$, Saša Orlovićc ${ }^{1}$, Milica Kovač², Irina Andreeva ${ }^{3}$, Ivan Vasenev ${ }^{3}$ \\ 1 University of Novi Sad, Institute of Lowland Forestry and Environment, Novi Sad, Serbia \\ 2 University of Novi Sad, Faculty of Agriculture, Novi Sad, Serbia \\ 3 Russian State Agrarian University - Moscow Timiryazev Agricultural Academy, Moscow, Russian \\ Federation \\ * Corresponding author: Miljan Samardžić; E-mail: miljan.samardzic@gmail.com
}

Received: 17 May 2021; Revised: 6 Sep 2021; Accepted: 8 Sep 2021

\begin{abstract}
Global changes, triggered by increased anthropogenic emissions of greenhouse gases, are the main problem of modern ecology. Soil is the main terrestrial reservoir of carbon, in both organic and inorganic forms. Forests are the major asset in carbon cycling and the mitigation of global climate change in the terrestrial ecosystem, because forest ecosystems in a temperate climate area are the major sink of $\mathrm{CO}_{2}$ from the atmosphere. Carbon dioxide emission from the soil is the major component of greenhouse gas emission, as well as the main respiratory flux from most forest ecosystems. In circumstances of changed climate and increased frequency of extreme climate events, soil greenhouse gas emission from forest ecosystems is gaining more and more importance, having in mind that soil temperature is one of the main limitation factors of greenhouse gas emission from the soil. From the results obtained from the experiment it is evident that the unusually warm winter of 2019/20 had as a consequence higher emission of greenhouse gases from all three experimental plots. Differences in emission between plots and between days can be explained by three main factors: soil composition, temperature difference between days of sampling, and soil moisture content. With an increased frequency of extreme climate events, as a consequence of global climate changes, the occurrence of higher winter temperatures is expected to be more frequent in the future, affecting also higher emission of greenhouse gases from the soil.
\end{abstract}

Keywords: global changes, $\mathrm{CO}_{2}$, emission, soil, winter.

\section{Introduction}

Global changes, triggered by increased anthropogenic emissions of greenhouse gases, are the main problem of modern ecology (IPCC, 2006, 2007, 2013, 2019). Currently, anthropogenic emissions of greenhouse gases are about 350 billion tons/year. It is estimated that around $8 \mathrm{Pg} \mathrm{C}$ are emitted by anthropogenic sources each year, and $3 \mathrm{Pg} \mathrm{C}$ are re-absorbed by the terrestrial biosphere. Soil is the main terrestrial reservoir of carbon, and $\mathrm{C}$ content in the soil is three times larger than $\mathrm{C}$ content in the 
atmosphere and five times larger than Carbon content of biota (Chang et al. 2016), and the global flux

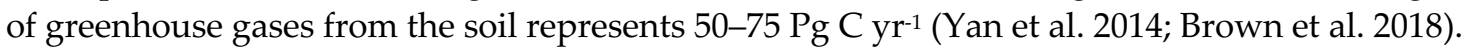

Forests are the major asset in carbon cycling and the mitigation of global climate change in terrestrial ecosystem, because forest ecosystems in temperate climate area are the major sink of $\mathrm{CO}_{2}$ from the atmosphere (Tubiello et al. 2014; Mayer et al. 2017). Poplar plantations have potential for rapid tree biomass production, and consequently fast accumulation of $C$, which can lead to the net $C$ sink in poplar plantations in 5-7 years, depending on the plantation's silviculture and soil conditions (Chang et al. 2016).

Carbon dioxide emission from the soil is the major component of greenhouse gas emission as well as the main respiratory flux from most forest ecosystems. Soil respiration can be divided into two major components: autotrophic (respiration of roots and associated microorganisms) and heterotrophic soil respiration (microbial decomposition of organic material). Soil organic C output is mainly dependent on microbial soil respiration, which shows a great deal of diurnal and seasonal variability (Chang et al. 2016). From that reason, it is necessary to know the main limitation factors of soil biological activity and consequently greenhouse gas emission from the soil, namely temperature. Soil moisture is not significant limitation factor in the soil $\mathrm{CO}_{2}$ production, except in the cases of moisture extremes, either very wet or very dry (Andrews et al. 2001).

The objective of this study was obtaining of data on greenhouse gas emission, $\mathrm{CO}_{2}$ and other greenhouse gases recalculated on $\mathrm{CO}_{2}$ equivalent $\left(\mathrm{CO}_{2} \mathrm{e}\right)$, in the abnormal winter temperature conditions.

\section{Material and methods}

\subsection{Site description}

The study was conducted at the "Kaćka šuma" experimental forest estate, on three research plots

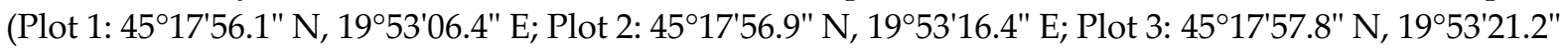
E), and based on soil respiratory chambers. The soil type on all plots was fluvisol, subtype calcareous, variety moderately deep. The main differences were in soil form. Two plots are on the lighter - sandy form (plots 2 and 3), and one plot is on the heavier - clay form (plot 1), near the irrigation channel. Textural class in humus accumulative horizon was loamy sand, calcareous, and $\mathrm{pH}$ neutral (Galic et al. 2009). Low humus content was determined in this horizon. The age of poplar trees at all three plots is sixteen years, and the poplar clone is from Populus deltoides plantation. The greenhouse gas emission is expressed in grams of $\mathrm{CO}_{2}$ equivalent $\left(\mathrm{g} \mathrm{CO}_{2} \mathrm{e}\right)$.

\subsection{Design of the experiment}

As already mentioned, experiment is based on soil respiratory chambers, of patented design and methodology (Avilov et al. 2014). Bases of chambers were placed into the soil, to the depth of $5 \mathrm{~cm}$, and left for a week to let small roots to decay. Before sampling, the chamber is placed on the top of the base, in airtight condition, inside air is homogenised and sampled three times in one hour. Sampling of air from chambers was performed as a part of long time experiment on greenhouse gas emission. Sampling of emission was performed at each research plot once in every ten days, with fifth fold repeatability (Tembo et al. 2014). Samples were analysed on gas chromatograph Agilent 8890 (Agilent Technologies, Santa Clara, California, USA). Statistical analysis of obtained data was performed by Statistica 12 (StatSoft, Inc., 2012) program package.

\section{Results and discussion}

Winter of 2019 was unusually warm, with daily temperatures on the "Kaćka šuma" locality at the sampling dates given in table 1 . The mean temperature for Novi Sad and its surroundings in the period 
1981 - 2010 for November was $5.9^{\circ} \mathrm{C}$, and for December was $1.5^{\circ} \mathrm{C}$ (http://www.hidmet.gov.rs), and the amount of precipitation was $61 \mathrm{~mm}$. According to data from Republic Hydrometeorological Service of Serbia, on the basis of the one-month SPI-1 drought/humidity index, determined for December 2019, normal humidity conditions prevailed. Soil moisture reserve varied from $58 \mathrm{~mm}$ in the first decade of December to $101 \mathrm{~mm}$ to the third decade of December. No significant difference in temperature was detected between plots.

Table 1. Daily minimum, maximum and mean air temperatures at the "Kaćka šuma" locality at sampling dates.

\begin{tabular}{cccc}
\hline \multirow{2}{*}{ Date } & \multicolumn{3}{c}{ Air temperature $\left({ }^{\circ} \mathbf{C}\right)$} \\
\cline { 2 - 4 } & Daily minimum & Daily mean & Daily maximum \\
\hline December $24^{\text {th }}, 2019$ & 2.3 & 7.4 & 10.9 \\
December $16^{\text {th }}, 2019$ & 2.1 & 6.6 & 14.8 \\
December $6^{\text {th }}, 2019$ & -0.9 & 1.0 & 4.2 \\
${\text { November } 22^{\text {th }}, 2019}^{2.9}$ & 2.9 & 8.2 & 13.9 \\
\hline
\end{tabular}

It is obvious that daily mean temperature during sampling was significantly higher than long term average, which, with abovementioned increased soil moisture, made corresponding soil microbial activity consequently higher, which have as a result increased greenhouse gas emission from the forest soil (Tembo et al. 2014; Chang et al. 2016; Brown et al. 2018).

The results on greenhouse gases emission (Figure 1) have shown that emission was the highest on the day when soil was the warmest (coinciding with sharp drop in air temperatures); also, significantly high emission was observed on the other warm days, as well as at the end of December, when soil moisture content was doubled compared to the first decade of December 2019. The differences in soil greenhouse gases emission between plots can be explained by different textural composition of the soil at different experimental plots (Tembo et al. 2014). From the presented data it is evident that during unusually warm winter 2019/20 emission of greenhouse gases was increased because high temperatures, which characterised whole winter period, had significant contribution of the soil moisture (Tembo et al. 2014, Chang et al. 2016; Brown et al. 2018).

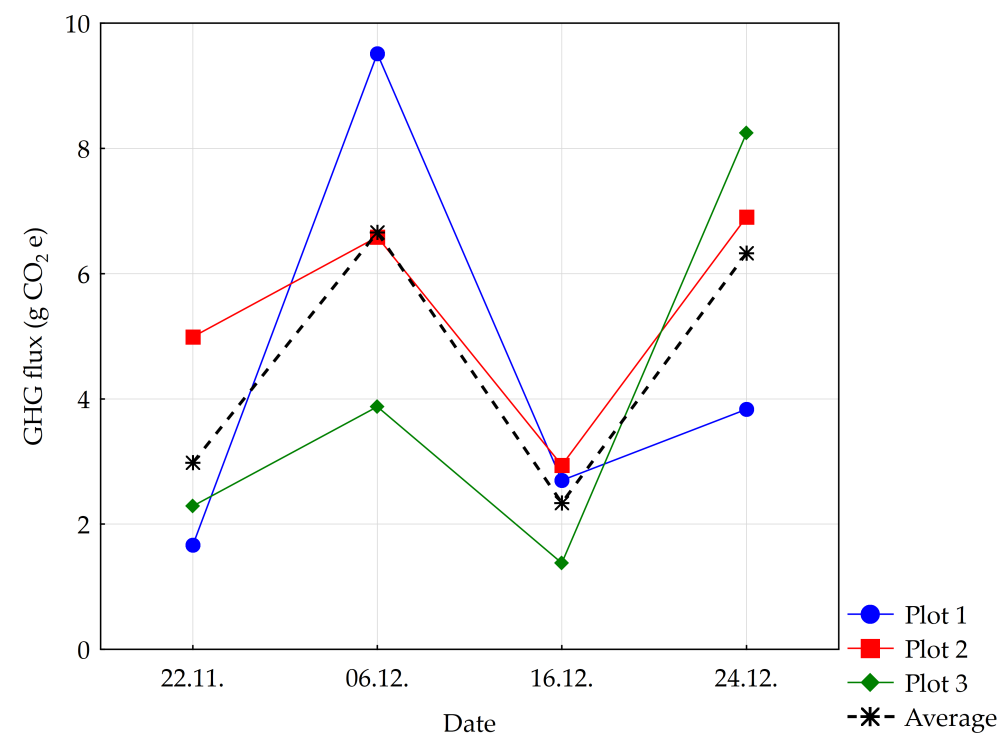

Figure 1. Greenhouse gases emission by plots and by dates.

Summary emission of greenhouse gases for all three plots on sampling days, as well as average, has shown that the highest emission was surprisingly observed on the coldest day (Figure 1) for the 
plot with heavier type of fluvisol, with different water-air characteristics, compared to the other two plots, which as a consequence had lesser soil temperature loss comparing to the other two plots. Also, the lowest emission is observed on the second hottest day in the sampling period. Those two discrepancies could be explained by different rate of soil cooling and heating, compared to the air temperature (e.g. on the coldest day, soil was sufficiently warm by heat accumulation and vice versa, in ten days, soil has not warmed up after period of several cold days) (Tembo et al. 2014). Also, very similar values for greenhouse emission on $16^{\text {th }}$ of December on all three plots are excellent proof that soil microbial and root activity, and consequently greenhouse gases emission from the soil is reduced due to the main limitation factor - temperature (Chang et al. 2016; Brown et al. 2018).

The two experimental plots positioned on the lighter subtypes are showing fairly uniformed results on the emission, compared to the plot on the heavier soil, which can be explained by soil textural composition, and consequently to water and air characteristics of the soil and activity of the microorganisms and roots.

\section{Conclusion}

From results obtained from the experiment it is evident that unusually warm winter 2019/20 influenced higher emission of greenhouse gases from all three experimental plots. Differences in emission between plots and between days can be explained by three main factors: soil composition, temperature difference between days of sampling and soil moisture content. At the moment when soil temperature was the lowest, value of greenhouse flux was almost uniform, which proved that temperature is the main limitation factor in greenhouse gases emission from the soil in the conditions of poplar plantations in Kać.

Global climate changes are leading to the increased frequency of extreme climate conditions, which are expressed through occurrence of higher winter temperatures and, consequently, higher emission of greenhouse gases from the soil.

\section{Acknowledgement}

This paper financed by the Ministry of Education, Science and Technological Development of the Republic of Serbia, Project No. 451-03-9/2021-14/200197. Special thanks for reviewers' suggestions in revision process of this paper.

\section{References}

1. Andrews, J., Schlesinger, W. (2001): Soil $\mathrm{CO}_{2}$ dynamics, acidification, and chemical weathering in a temperate forest with experimental $\mathrm{CO}_{2}$ enrichment. Global biogeochemical cycles 15(1): 149-162.

2. Avilov, V., Barkov, V., Vasenev, I.,Vasenev, V., Vizirskaja, M., Peskarev, A., Terekhov, A., Kurbatova, Ju., Samardzhich, M. (2014): Device for measuring emission of greenhouse gas from soil and plants. Federal service for intellectual property patent RU 2518979 C1, Moscow, Russian Federation.

3. Brown, R., Markewitz, D. (2018): Soil heterotrophic respiration: Measuring and modeling seasonal variation and silvicultural impacts. Forest Ecology and Management 430: 594-608.

4. Chang, S.X., Shi, Z., Thomas, B.R. (2016): Soil respiration and its temperature sensitivity in agricultural and afforested poplar plantation systems in northern Alberta. Biology and Fertility of Soils 52: 629-641.

5. Galić Z., Ivanišević P., Orlović S., Redei K., Pekeč S., Kebert M. (2009): Monitoring sezonske dinamike vlažnosti aluvijalnog zemljišta u priobalju Dunava kod Novog Sada. Topola 183/84: $5-20$. 
6. IPCC (2006): Guidelines for national greenhouse gas inventories. Volume 4, chapter 10: Agriculture, Forestry and Other Land Use. Land Use Change and Forestry. Cambridge University Press, Cambridge, United Kingdom and New York, NY, USA.

7. IPCC (2007): Climate change 2007: the physical science basis. Solomon, S., Qin, D., Manning, M., Chen, Z., Marquis, M., Averyt, K.B., Tignor, M., Miller, H.L. (eds.). Contribution of Working Group I to the Fourth assessment report of the Intergovernmental panel on climate change. Cambridge University Press, Cambridge, United Kingdom and New York, NY, USA.

8. IPCC (2013): Climate change 2013: the physical science basis. Stocker, T.F., Qin, D., Plattner, GK., Tignor, M., Allen, S.K., Boschung, J., Nauels, A., Xia, Y., Bex, V., Midgley, P.M. (eds.). Working Group I contribution to the Fifth assessment report of the Intergovernmental panel on climate change. Cambridge University Press, Cambridge, United Kingdom and New York, NY, USA.

9. IPCC (2019): 2019 refinement to the 2006 IPCC guidelines for national greenhouse gas inventories, Volume 4. Calvo Buendia, E., Tanabe, K., Kranjc, A., Baasansuren, J., Fukuda, M., Ngarize S., Osako, A., Pyrozhenko, Y., Shermanau, P., Federici, S. (eds). Agriculture, Forestry and Other Land Use. IPCC, Switzerland.

10. Mayer, M., Sanden, H., Rewald, B., Godbold, D.L., Katzensteiner, K. (2017): Increase in heterotrophic soil respiration by temperature drives decline in soil organic carbon stocks after forest windthrow in a mountainous ecosystem. Functional Ecology 31: 1163-1172.

11. StatSoft, Inc (2012): STATISTICA (data analysis software system), version 12. www.statsoft.com

12. Republic Hydrometeorological Service of Serbia http://www.hidmet.gov.rs/eng/meteorologija/stanica_sr.php?moss_id=13168 [accessed 27 April 2021]

13. Tubiello, F.N., Salvatore, M., Cóndor Golec, R.D., Ferrara, A., Rossi, S., Biancalani, R., Federici, S., Jacobs, H., Flammini, A. (2014): Agriculture, forestry and other land use emissions by sources and removals by sinks 1990-2011 analysis. FAO, Rome: 54

14. Yan, M., Guo, N., Ren, H., Zhang, X., Zhou, G. (2015): Autotrophic and heterotrophic respiration of a poplar plantation chronosequence in northwest China. Forest Ecology and Management 337: 119-125.

15. Тембо, А., Самарджич, М., Васенев, В.И., Рыжков, О.В., Морев, Д.В., Васенев, И.И. (2014): Анализ основных факторов, вдияющих на почвенную эмиссию углекислого газа черноземами Стрелецкой степи. Современные проблемы науки и образования. № 2.; URL: http://www.science-education.ru/ru/article/view?id=12864 (дата обращения: 20.04.2021). 